\title{
Editorial for Special Issue "Towards a Sustainable Management of Mine Wastes: Reprocessing, Reuse, Revalorization, and Repository"
}

\author{
Yassine Taha ${ }^{1, *(D)}$ and Mostafa Benzaazoua ${ }^{1,2, *(D)}$ \\ 1 Materials Science and Nano-Engineering Department, Mohammed VI Polytechnic University, Lot 660, \\ Hay Moulay Rachid, Ben Guerir 43150, Morocco \\ 2 Institut de Recherche en Mines et Environnement (IRME), Université du Québec en \\ Abitibi-Témiscamingue (UQAT), 445 Boul de l'Université, Rouyn-Noranda, QC J9X 5E4, Canada \\ * Correspondence: Yassine.TAHA@um6p.ma (Y.T.); Mostafa.Benzaazoua@uqat.ca (M.B.)
}

Received: 20 December 2019; Accepted: 24 December 2019; Published: 25 December 2019

The mining industry continues to face many challenges due to its potential environmental impacts. These challenges are becoming harder to overcome with growing social awareness, increasing governmental pressure on disposal alternatives, and the scarcity of available spaces for waste disposal [1]. The need to manage mine wastes in a sustainable way also continues to grow. In this Special Issue, research papers in the form of reviews, articles, technical notes, and case studies about the sustainable management of mine wastes were selected. Different approaches and management strategies have been developed by researchers from all around the world. The papers presented in this Special Issue consider the social, economic, environmental, and technical aspects of sustainable management of mine wastes. Many different types of mine wastes can be produced during a mine's life cycle (Figure 1), and the choice of methods for managing them depends on many factors. Therefore, the developed solutions are generally very site-specific and difficult to apply in other cases.

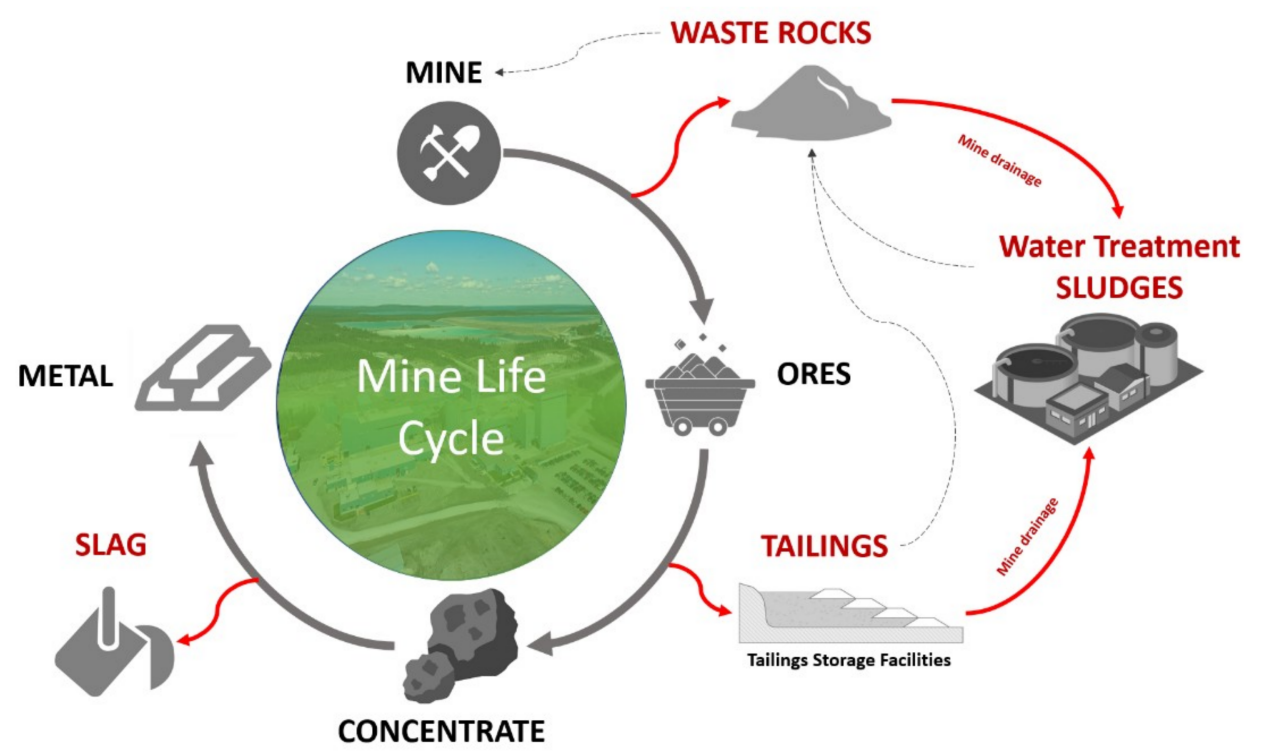

Figure 1. A mine's life cycle and types of mine wastes.

A systematic review paper from the University of Almeria (Spain), based on a bibliometric analysis of a sample of 3577 articles from 1988 to 2017, analyzed the dynamics of research focused on mining 
wastes and their sustainable management [2]. The results indicated an increase in the number of published papers about mining wastes due to an increase in attention to, and the growing social awareness about, mining wastes. It was revealed also that the United States, followed by Canada, Spain, Australia, and China are the countries that produce the most papers in mine waste management. Remediation, reuse, and evaluation of the potential alternative uses of mining wastes are the most currently studied aspects since they allow for the mine industry to subscribe to the circular economy, and allow for the mining industry to have a smaller ecological footprint. The sustainable management of mining wastes and the contribution of mine waste management to sustainability is an emerging field of research that has considerable potential due to the increased demand for natural resources and for sustainable practices.

Another review paper from the University of Queensland (Australia) investigated current knowledge about mining waste management and the possible opportunities related to the application of circular economy thinking to mine wastes [3]. Five key areas were explored (Figure 2): social dimensions, geoenvironmental aspects, geometallurgy specifications, economic drivers, and legal implications. Much research work remains necessary to identify efficient and effective solutions in each key area, as these kinds of approaches require cross-disciplinary skills to transform waste materials into more valuable resources.

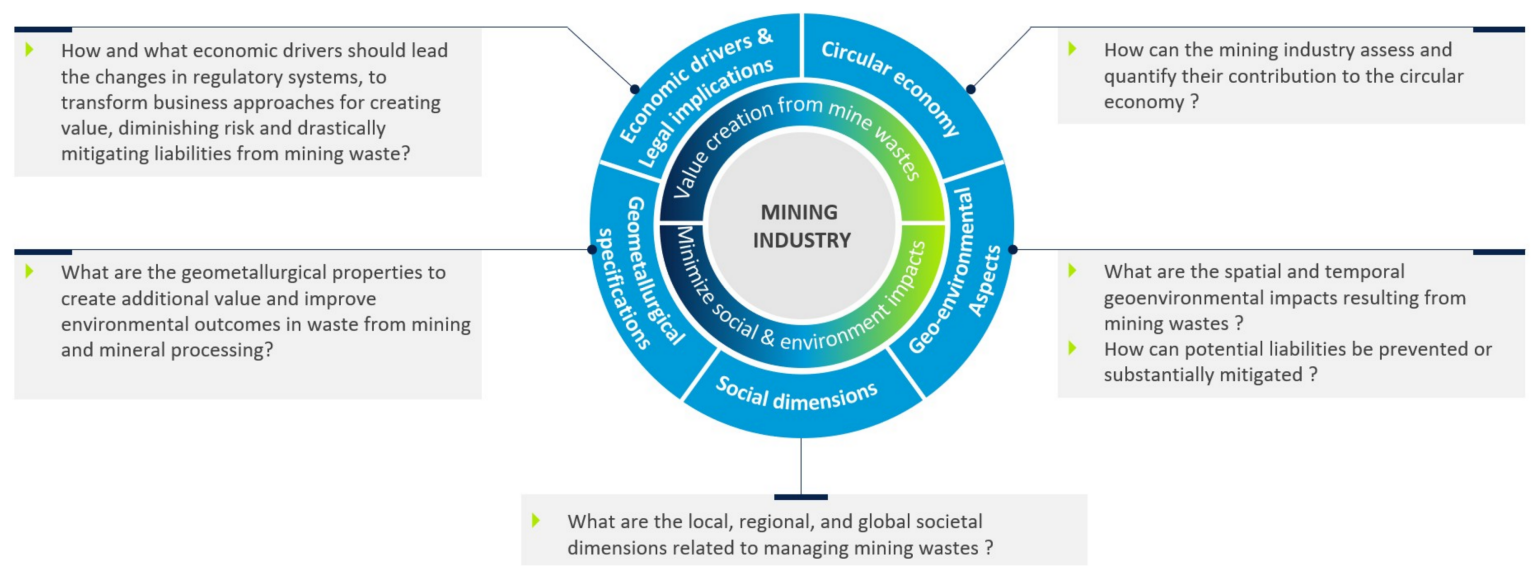

Figure 2. Key areas of an integrative approach to mining waste management (adapted from [3]).

The evaluation of the environmental impacts of mine wastes has been also included in this Special Issue through different articles. Acid mine drainage (AMD) from sulfidic and oxidized ores and the related impacts on the geochemical behavior of mine wastes and pollutant mobility were assessed. A new predictive methodology based on ore mineralogy and contaminant speciation was developed by Chopard et al. [4]. It was concluded in this study that it is possible to improve waste management practices and mine closure planning, while saving time and money thanks to an earlier detection of the environmental impacts of mine wastes from the beginning of the mine development phase. In the case of closed mines, geochemical properties in an oxidized tailings storage facility (TSF) were evaluated by Elghali et al. [5]. The spatial variability of the geochemical properties of tailings in the TSF is mainly governed by the formation of hardpans at the subsurface of the tailings. The goal of the study was also to identify the most appropriate reclamation scenario for each area based on a geographic information system (GIS)-based approach and multi-technique characterization.

The environmental desulfurization of sulfidic tailings was used to depollute tailings by removing the problematic residual sulfides in different metallic and nonmetallic tailings [6,7]. This technique was applied by Nadeif et al. [8] to reprocess tailings from an abandoned mine to avoid acid mine drainage and to recover the residual metals $(\mathrm{Au}, \mathrm{Ag}$, and $\mathrm{Cu}$ ). The same approach was adopted by Drif et al. [9], who succeeded in recovering silver-bearing minerals, mainly in the form of sulfides, from low-grade tailings by froth flotation processing. By doing so, the authors proved that the cleaned 
tailings are inert and do not present any leaching risk according to a toxicity characteristic leaching procedure test (TCLP). Another method was developed by Crane and Sapsford [10], who assessed the performance of a leaching-based remediation approach using greener lixiviants for the recovery of value from legacy mine wastes and tailings. The results of this study demonstrated that the use of organic acids could provide similar As and $\mathrm{Cu}$ recovery efficiencies while preserving the environment. Moreover, this Special Issue also presents information about a hydrothermal method that was used to recover alkali from Bayer red mud using $\mathrm{CaO}$ and/or $\mathrm{MgO}$ for resource utilization and environmental protection [11]. As an example of mine waste that could have economic potential, historic tailings from the gravity separation process in an old Bergwerkswohlfahrt mine waste dump in Germany were investigated. The spatial distribution of valuable metals ( $\mathrm{Pb}, \mathrm{Zn}, \mathrm{Cu}, \mathrm{Ag}$, and $\mathrm{Sb}$ ) was assessed using a laser-induced breakdown spectroscopy (LIBS) core scanner coupled with other textural, geochemical, and mineralogical characterization techniques. The results of this study demonstrated that a total tonnage close to $8000 \mathrm{t}$ of lead and 610,000 ounces of silver could be recovered from these tailings. Finally, in the framework of circular economy objectives, a technical note has focused on the integrated management of iron ore tailings by recovering the residual iron and preparing concrete composites from high silica residues and blast furnace slag [12].

As is the case in many developing countries where environmental policies and practices remain underdeveloped, it was reported that, due to many years of unregulated and unsustainable mining activities, large volumes of disposed mine tailings could present various environmental risks related to the potential mobility of toxic chemical species into surface and groundwater systems [13]. Gitari et al. [13] present the case of copper mine wastes from Musina in South Africa. After a characterization of tailings and leachates, it was concluded that the mobility of potentially toxic chemical species to the aqueous phase was very low. This was explained mainly by the adsorption of metals to the surface of precipitated hematite.

In the contrary, in developed countries such as Canada, local regulation obliges every closed mine site to be rehabilitated. At least some mitigating techniques can be applied successfully. This was found to be the case at the Joutel mine site, where stabilization of acidic tailings was investigated to allow for improvement in the effluents' quality before final mine reclamation [14]. In this context, Elghali et al. [14] assessed the effectiveness of alkaline and cementitious additives (limestones, ordinary Portland cement, and fly ash) for the neutralization and stabilization of acid-generating tailings from a closed gold mine in Quebec, Canada. The results highlighted the efficiency of the used additives in increasing $\mathrm{pH}$ to circumneutral values and decreasing the release of metals/metalloids.

Cemented paste backfill was also investigated as another option for the disposal of tailings. This option is widely used due to its environmental and economic benefits. However, many parameters could affect the quality of the cemented backfill, including the quality of the tailings and the mixing performance. Therefore, the effect of high mixing intensity on the rheological properties of cemented paste backfill was investigated by Yang et al. [15]. It was demonstrated that the mixing intensity affects the rheological behavior of the paste backfill.

Conflicts of Interest: The authors declare no conflict of interest.

\section{References}

1. Taha, Y.; Benzaazoua, M.; Hakkou, R.; Mansori, M. Natural clay substitution by calamine processing wastes to manufacture fired bricks. J. Clean. Prod. 2016, 135, 847-858. [CrossRef]

2. Aznar-Sánchez, J.A.; García-Gómez, J.J.; Velasco-Muñoz, J.F.; Carretero-Gómez, A. Mining waste and its sustainable management: Advances in worldwide research. Minerals 2018, 8, 284. [CrossRef]

3. Tayebi-Khorami, M.; Edraki, M.; Corder, G.; Golev, A. Re-Thinking Mining Waste through an Integrative Approach Led by Circular Economy Aspirations. Minerals 2019, 9, 286. [CrossRef]

4. Chopard, A.; Marion, P.; Mermillod-Blondin, R.; Plante, B.; Benzaazoua, M. Environmental Impact of Mine Exploitation: An Early Predictive Methodology Based on Ore Mineralogy and Contaminant Speciation. Minerals 2019, 9, 397. [CrossRef] 
5. Elghali, A.; Benzaazoua, M.; Bussière, B.; Genty, T. Spatial Mapping of Acidity and Geochemical Properties of Oxidized Tailings within the Former Eagle/Telbel Mine Site. Minerals 2019, 9, 180. [CrossRef]

6. Benzaazoua, M.; Bussière, B.; Demers, I.; Aubertin, M.; Fried, É.; Blier, A. Integrated mine tailings management by combining environmental desulphurization and cemented paste backfill: Application to mine Doyon, Quebec, Canada. Miner. Eng. 2008, 21, 330-340. [CrossRef]

7. Çelik, M.; Yildirim, I. A new physical process for desulfurization of low-rank coals. Fuel 2000, 79, 1665-1669. [CrossRef]

8. Nadeif, A.; Taha, Y.; Bouzahzah, H.; Hakkou, R.; Benzaazoua, M. Desulfurization of the Old Tailings at the Au-Ag-Cu Tiouit Mine (Anti-Atlas Morocco). Minerals 2019, 9, 401. [CrossRef]

9. Drif, B.; Taha, Y.; Hakkou, R.; Benzaazoua, M. Recovery of Residual Silver-Bearing Minerals from Low-Grade Tailings by Froth Flotation: The Case of Zgounder Mine, Morocco. Minerals 2018, 8, 273. [CrossRef]

10. Crane, R.; Sapsford, D. Towards Greener Lixiviants in Value Recovery from Mine Wastes: Efficacy of Organic Acids for the Dissolution of Copper and Arsenic from Legacy Mine Tailings. Minerals 2018, 8, 383. [CrossRef]

11. Zhou, B.; Cao, S.; Chen, F.; Zhang, F.; Zhang, Y. Recovery of Alkali from Bayer Red Mud Using CaO and/or MgO. Minerals 2019, 9, 269. [CrossRef]

12. Tang, C.; Li, K.; Ni, W.; Fan, D. Recovering Iron from Iron Ore Tailings and Preparing Concrete Composite Admixtures. Minerals 2019, 9, 232. [CrossRef]

13. Gitari, W.; Thobakgale, R.; Akinyemi, S. Mobility and Attenuation Dynamics of Potentially Toxic Chemical Species at an Abandoned Copper Mine Tailings Dump. Minerals 2018, 8, 64. [CrossRef]

14. Elghali, A.; Benzaazoua, M.; Bussière, B.; Genty, T. In Situ Effectiveness of Alkaline and Cementitious Amendments to Stabilize Oxidized Acid-Generating Tailings. Minerals 2019, 9, 314. [CrossRef]

15. Yang, L.; Wang, H.; Li, H.; Zhou, X. Effect of High Mixing Intensity on Rheological Properties of Cemented Paste Backfill. Minerals 2019, 9, 240. [CrossRef]

(C) 2019 by the authors. Licensee MDPI, Basel, Switzerland. This article is an open access article distributed under the terms and conditions of the Creative Commons Attribution (CC BY) license (http://creativecommons.org/licenses/by/4.0/). 